\title{
Research on existing problems and improvement measures of bidding for construction projects
}

\author{
Ruifu Cui ${ }^{1,}$, , Huihui Yang ${ }^{2, b^{*}}$,Mingzhen Wang ${ }^{3, c}$ and Lin Gao ${ }^{4, d}$ \\ ${ }^{1}$ Chongqing University Of Arts And Sciences, Yong Chuan District,Chongqing \\ ${ }^{2}$ Chongqing University Of Arts And Sciences, Yong Chuan District,Chongqing \\ ${ }^{3}$ Chongqing University Of Arts And Sciences, Yong Chuan District,Chongqing \\ ${ }^{4}$ Chongqing University Of Arts And Sciences, Yong Chuan District,Chongqing \\ a874613204@qq.com, b522143137@qq.com, c843763110@qq.com, d523674248@qq.com
}

Keywords: Project construction; bidding; existing problems; improvement measures

Abstract. In this paper, the problems existing in different bidding stages of each bid participant are first sorted out through the list,Then put forward the corresponding improvement measures to the problems in the bidding And put forward suggestions for the bidding activities in our country,ensure that the transaction of public resources for construction projects is truly fair, fair and efficient.

\section{Overview of bidding for construction projects}

Meaning of bidding for construction projects. Since the introduction of construction project bidding into our country, it has become an important means of engineering transaction in our country. Construction project bidding refers to the process that the tenderer issues an invitation, the bidder makes a commitment to it, selects the best bidder (i.e. the winning bidder ) through fair competition, and reaches an agreement with it and enters into a contract.

Participants and procedures of bidding for construction projects. The main parties directly involved in the bidding of construction projects are the tenderer, the bidder, the bidding agency, the bid evaluation experts, the administrative supervision and management departments [1] and other five parties. This article divides the main procedures of bidding for construction projects in our country [2]into:1 ) Preparatory stage, It mainly includes the project establishment, approval and construction application, Project funds in place, Tender approval, tender announcement and preparation of tender documents.2) Stage before bid opening and evaluation, It mainly includes the release of tender information, registration, qualification examination, sale of tender documents, on-site reconnaissance, answering questions, preparation and submission of tender documents.3 ) Bid opening and evaluation stage, It mainly includes the bid opening, evaluation and calibration of the project.4) Late stage, It mainly includes the announcement of winning the bid, the notice of winning the bid, the sorting and filing of documents and materials after the bid evaluation, and the signing of the contract, etc.

\section{Problems in bidding for construction projects}

In the field of engineering construction, the most common trading method is bidding for construction projects, whether it is goods purchasing or engineering construction. It has been nearly 30 years since China implemented the bidding system in the last century. The implementation of the bidding system has effectively solved the irregularities in the purchase of goods and the transaction of construction projects. In recent years, the state and local governments at all levels have issued a series of laws, regulations and rules related to bidding. So that the bidding process can be continuously improved and perfected, The system and procedures ensure the openness, fairness and fairness of the bidding, thus improving the quality of the construction project. At the same time, the construction cost is also reduced. At the same time of obtaining the greatest benefits, it also provides a good trading environment for the society. Even so, there are a lot of problems to be solved in the actual bidding 
process. The following uses a tabular form to explain the problems and improvement measures of each participant in the bidding of construction projects at each stage ( see table 1 ):

table 1 Problems and improvement measures of each participant in each stage

\begin{tabular}{|c|c|c|c|}
\hline \multicolumn{2}{|c|}{ Participants } & Existing problem & Improvement measures \\
\hline \multirow[t]{4}{*}{ Tenderer } & $\begin{array}{l}\text { Preparatory } \\
\text { stage }\end{array}$ & $\begin{array}{l}\text { (1) When the tenderer establishes a } \\
\text { project, he will dismember or split } \\
\text { the same project into multiple } \\
\text { projects, or evade the project } \\
\text { establishment and bidding under the } \\
\text { guise of a collective. } \\
\text { (2) The tender's preparation of the } \\
\text { tender documents is rough or the } \\
\text { content and terms are not clearly set, } \\
\text { resulting in the loss of interests of } \\
\text { the tenderer. } \\
\text { (3)The examination and approval of } \\
\text { the tender documents are only mere } \\
\text { formality, but the basic contents are } \\
\text { not examined and approved in } \\
\text { place, and the checks are not strict. } \\
\text { (4) The content of the tender } \\
\text { documents restricts or excludes } \\
\text { potential bidders from other } \\
\text { regions, which has strong local } \\
\text { protection color. } \\
\text { (5) The tenderer shall set the } \\
\text { winning bidder as the condition to } \\
\text { choose the bidding agency. }\end{array}$ & $\begin{array}{l}\text { (1) Establish and perfect national } \\
\text { laws and regulations, and strengthen } \\
\text { law enforcement and administrative } \\
\text { supervision. } \\
\text { (2) Strengthen business learning and } \\
\text { enhance the business capabilities of } \\
\text { all parties involved in bidding. } \\
\text { (3) Implement all approval } \\
\text { procedures to the people and } \\
\text { implement the accountability } \\
\text { system. }\end{array}$ \\
\hline & $\begin{array}{l}\text { Stage before } \\
\text { bid opening } \\
\text { and } \\
\text { evaluation }\end{array}$ & $\begin{array}{l}\text { (1) The tenderer divulges } \\
\text { information about the pretender } \\
\text { estimate and other projects and sells } \\
\text { the interests of the state and the } \\
\text { collective. } \\
\text { (2) The tenderer controls the } \\
\text { bidding information and makes } \\
\text { false bidding. }\end{array}$ & $\begin{array}{l}\text { (1) Intensify publicity of laws and } \\
\text { regulations and implement } \\
\text { multi-sectoral joint and coordinated } \\
\text { law enforcement. } \\
\text { (2) To further strengthen the } \\
\text { information disclosure and make the } \\
\text { bidding open and transparent. }\end{array}$ \\
\hline & $\begin{array}{l}\text { Bid opening } \\
\text { and } \\
\text { evaluation } \\
\text { stage }\end{array}$ & $\begin{array}{l}\text { (1) The tenderer induces or } \\
\text { interferes with the evaluation of } \\
\text { bids by evaluation experts. } \\
\text { (2) The tenderer hinted that some } \\
\text { specific bidders had bid rigging and } \\
\text { bid rigging. }\end{array}$ & $\begin{array}{l}\text { (1) Strictly enforce the law and } \\
\text { crack down on illegal and criminal } \\
\text { acts. } \\
\text { (2) Perfect the system of laws and } \\
\text { regulations and increase the cost of } \\
\text { illegal crimes. }\end{array}$ \\
\hline & Late stage & $\begin{array}{l}\text { (1) The tenderer does not issue the } \\
\text { bid-winning notice. } \\
\text { (2) There is a substantial difference } \\
\text { between the contents of the contract } \\
\text { signed and the tender documents, or } \\
\text { a supplementary agreement outside } \\
\text { the scope of the tender. }\end{array}$ & $\begin{array}{l}\text { (1) Establish and perfect national } \\
\text { laws and regulations, and strengthen } \\
\text { law enforcement and administrative } \\
\text { supervision. } \\
\text { (2) It is suggested to implement a } \\
\text { double filing system of bidding } \\
\text { documents and contracts to } \\
\text { strengthen the punishment of illegal } \\
\text { activities. }\end{array}$ \\
\hline
\end{tabular}




\begin{tabular}{|c|c|c|c|}
\hline \multirow{4}{*}{ Bidder } & $\begin{array}{l}\text { Preparatory } \\
\text { stage }\end{array}$ & $\begin{array}{l}\text { (1) Bidders know the project } \\
\text { information in advance through } \\
\text { bribery and other means so as to } \\
\text { prepare in advance as well as " } \\
\text { Bribery". }\end{array}$ & $\begin{array}{l}\text { (1) Emphasis is placed on crime } \\
\text { prevention, followed by severe } \\
\text { investigation. } \\
\text { (2) Establish and perfect the credit } \\
\text { quality system and link it with bank } \\
\text { credit reporting to prevent illegal } \\
\text { activities. }\end{array}$ \\
\hline & $\begin{array}{l}\text { Stage before } \\
\text { bid opening } \\
\text { and } \\
\text { evaluation }\end{array}$ & $\begin{array}{l}\text { (1) The bidder bought the tender's } \\
\text { staff, bidding agency and bid } \\
\text { evaluation experts in advance to } \\
\text { serve his bid. }\end{array}$ & $\begin{array}{l}\text { (1) Intensify publicity of laws and } \\
\text { regulations and implement } \\
\text { multi-sectoral joint and coordinated } \\
\text { law enforcement. } \\
\text { (2) Perfect the system of laws and } \\
\text { regulations and increase the cost of } \\
\text { illegal crimes. }\end{array}$ \\
\hline & $\begin{array}{l}\text { Bid opening } \\
\text { and } \\
\text { evaluation } \\
\text { stage }\end{array}$ & $\begin{array}{l}\text { (1) Bidders carry out bid rigging, } \\
\text { bid rigging, bid } \\
\text { accompanying[3]and other issues. } \\
\text { (2) Many problems such as bidders' } \\
\text { qualification to be affiliated have } \\
\text { been forbidden. } \\
\text { (3) Bidders blindly suppressed their } \\
\text { bids and won the bid at a price lower } \\
\text { than the cost. }\end{array}$ & $\begin{array}{l}\text { (1) Perfect the system of laws and } \\
\text { regulations and increase the cost of } \\
\text { illegal crimes. } \\
\text { (2) Once the problem of } \\
\text { qualification affiliation is } \\
\text { discovered, it will be dealt with } \\
\text { severely and will not be tolerated. } \\
\text { (3) Strictly manage the market to } \\
\text { approve admittance and withdrawal, } \\
\text { and implement the withdrawal } \\
\text { system. }\end{array}$ \\
\hline & Late & $\begin{array}{l}\text { (1)After winning the bid, the bidder } \\
\text { has illegally subcontracted and } \\
\text { subcontracted[4]and other } \\
\text { phenomena. } \\
\text { (2) Bidders blindly lower their bids } \\
\text { below the cost and do not sign } \\
\text { contracts after winning the bid. }\end{array}$ & $\begin{array}{l}\text { (1) Perfect the system of laws and } \\
\text { regulations and increase the cost of } \\
\text { illegal crimes. } \\
\text { (2) Increase the intensity of } \\
\text { guarantee and increase the cost of } \\
\text { illegal breach of contract. }\end{array}$ \\
\hline \multirow[t]{2}{*}{$\begin{array}{l}\text { Tenderin } \\
\text { g agency }\end{array}$} & $\begin{array}{l}\text { Preparatory } \\
\text { stage }\end{array}$ & $\begin{array}{l}\text { (1) The tendering agency } \\
\text { collaborates with the tenderee or } \\
\text { bidder to tailor the setting } \\
\text { conditions of the bidding } \\
\text { documents for specific bidders. } \\
\text { (2) The business level of bidding } \\
\text { agencies is uneven, the compilation } \\
\text { of bidding documents is chaotic, } \\
\text { and some agencies have very low } \\
\text { level. } \\
\text { (3) The problem of the qualification } \\
\text { of the agency is widespread. }\end{array}$ & $\begin{array}{l}\text { (1) Strengthen law enforcement and } \\
\text { administrative supervision and } \\
\text { establish integrity files. } \\
\text { (2) Enterprise points system can be } \\
\text { implemented, and enterprises that } \\
\text { fail to meet the annual standards can } \\
\text { be promptly returned. } \\
\text { (3) Regular and regular training of } \\
\text { bidding agencies to improve the } \\
\text { level of business capabilities. } \\
\text { (4) Once a qualified bidding agent is } \\
\text { found, it will be dealt with severely } \\
\text { and will not be tolerated. }\end{array}$ \\
\hline & $\begin{array}{l}\text { Stage before } \\
\text { bid opening } \\
\text { and } \\
\text { evaluation }\end{array}$ & $\begin{array}{l}\text { (1) The bidding agency leaked } \\
\text { information to the bidding unit it } \\
\text { intended. }\end{array}$ & $\begin{array}{l}\text { (1) Strengthen law enforcement and } \\
\text { administrative supervision and } \\
\text { establish integrity files. } \\
\text { (2)The administrative supervision } \\
\text { department shall appropriately } \\
\text { implement incentive and tender }\end{array}$ \\
\hline
\end{tabular}




\begin{tabular}{|c|c|c|c|}
\hline & & & $\begin{array}{l}\text { document appraisal measures to } \\
\text { guide the tender agency to develop } \\
\text { in the right direction. }\end{array}$ \\
\hline & $\begin{array}{l}\text { Bid opening } \\
\text { and } \\
\text { evaluation } \\
\text { stage }\end{array}$ & $\begin{array}{l}\text { (1) The tendering agency induces } \\
\text { and intervenes in bid evaluation so } \\
\text { that bid evaluation experts can } \\
\text { evaluate bids according to their } \\
\text { wishes. } \\
\text { (2) The tendering agency colluded } \\
\text { with the bid evaluation experts to } \\
\text { determine the intended bid winner. }\end{array}$ & $\begin{array}{l}\text { (1) Intensify publicity of laws and } \\
\text { regulations and implement } \\
\text { multi-sectoral joint and coordinated } \\
\text { law enforcement. } \\
\text { (2) Strictly control market access } \\
\text { and withdrawal, implement a system } \\
\text { of withdrawal and withdrawal, and } \\
\text { promptly clean up bidding agencies } \\
\text { that maliciously interfere with the } \\
\text { market. }\end{array}$ \\
\hline & Late stage & None & None \\
\hline \multirow{4}{*}{$\begin{array}{l}\text { Evaluati } \\
\text { on expert }\end{array}$} & $\begin{array}{l}\text { Preparatory } \\
\text { stage }\end{array}$ & None & None \\
\hline & $\begin{array}{l}\text { Stage before } \\
\text { bid opening } \\
\text { and } \\
\text { evaluation }\end{array}$ & $\begin{array}{l}\text { (1) A few experts have poor } \\
\text { professional qualities, accept bribes } \\
\text { and accept red packets. }\end{array}$ & $\begin{array}{l}\text { (1) Intensify publicity of laws and } \\
\text { regulations and punish illegal } \\
\text { crimes. }\end{array}$ \\
\hline & $\begin{array}{l}\text { Bid opening } \\
\text { and } \\
\text { evaluation } \\
\text { stage }\end{array}$ & $\begin{array}{l}\text { (1) The professional level of } \\
\text { evaluation experts is uneven, and a } \\
\text { few experts are overstaffed and } \\
\text { unable to do business. } \\
\text { (2) Because the clauses in the tender } \\
\text { documents are not carefully set up, } \\
\text { the subjective factors of the bid } \\
\text { evaluation experts account for a } \\
\text { large proportion, which affects the } \\
\text { fairness of bid evaluation. } \\
\text { (3) The evaluation time is too short, } \\
\text { resulting in low evaluation quality. }\end{array}$ & $\begin{array}{l}\text { (1) Carry out dynamic management } \\
\text { of the expert database in the region, } \\
\text { and clear out unqualified experts in } \\
\text { a timely manner. } \\
\text { (2) Establish a mechanism for } \\
\text { regular training and assessment of } \\
\text { experts to improve their } \\
\text { professional level. } \\
\text { (3) Refine the standards and } \\
\text { guidelines for bid evaluation and } \\
\text { reduce the subjective factors of bid } \\
\text { evaluation experts. } \\
\text { (4) According to factors such as the } \\
\text { size of the project, the bid } \\
\text { evaluation time standard should be } \\
\text { set appropriately. }\end{array}$ \\
\hline & Late stage & None & None \\
\hline \multirow{3}{*}{$\begin{array}{l}\text { Supervis } \\
\text { ion and } \\
\text { manage } \\
\text { ment } \\
\text { departm } \\
\text { ent }\end{array}$} & $\begin{array}{l}\text { Preparatory } \\
\text { stage }\end{array}$ & $\begin{array}{l}\text { (1) The examination and approval } \\
\text { of the project is not strict, resulting } \\
\text { in the project that should have been } \\
\text { subject to tender is not subject to } \\
\text { tender. } \\
\text { (2) Laws and regulations are not } \\
\text { perfect, and the degree of execution } \\
\text { is not enough. }\end{array}$ & $\begin{array}{l}\text { (1) Establish and perfect national } \\
\text { laws and regulations, and strengthen } \\
\text { law enforcement and administrative } \\
\text { supervision. } \\
\text { (2) Implement all approval } \\
\text { procedures to the people and } \\
\text { implement the accountability } \\
\text { system. }\end{array}$ \\
\hline & $\begin{array}{l}\text { Stage before } \\
\text { bid opening } \\
\text { and } \\
\text { evaluation }\end{array}$ & $\begin{array}{l}\text { (1) Tender information is not shared } \\
\text { across regions and trades. }\end{array}$ & $\begin{array}{l}\text { (1) To further strengthen the } \\
\text { information disclosure and make the } \\
\text { bidding open and transparent. }\end{array}$ \\
\hline & $\begin{array}{l}\text { Bid opening } \\
\text { and }\end{array}$ & $\begin{array}{l}\text { (1) There is no dynamic evaluation } \\
\text { and management mechanism for }\end{array}$ & $\begin{array}{l}\text { (1) The establishment of a dynamic } \\
\text { supervision and management }\end{array}$ \\
\hline
\end{tabular}




\begin{tabular}{|l|l|l|l|}
\hline $\begin{array}{l}\text { evaluation } \\
\text { stage }\end{array}$ & $\begin{array}{l}\text { supervision objects. } \\
\text { (2) The handling of illegal crimes is } \\
\text { too light. }\end{array}$ & $\begin{array}{l}\text { evaluation mechanism, increase the } \\
\text { intensity of illegal punishment, } \\
\text { increase the cost of illegal crimes. }\end{array}$ \\
\cline { 2 - 4 } Late stage & $\begin{array}{l}\text { (1) The supervision and } \\
\text { management system is not perfect. } \\
\text { at present, it is only feedback after } \\
\text { the event, and there is no prior and } \\
\text { in-process control. } \\
\text { (2) Integrity information is not } \\
\text { shared across regions and trades. }\end{array}$ & $\begin{array}{l}\text { (1) Establish the whole process } \\
\text { supervision and management } \\
\text { mechanism of prevention in } \\
\text { advance, control in the process and } \\
\text { feedback afterwards. } \\
\text { (2) To strengthen the national open } \\
\text { information construction and make } \\
\text { the bidding completely open and } \\
\text { transparent. }\end{array}$ \\
\hline
\end{tabular}

\section{Concluding remarks}

Bidding is an important link in the effective implementation of construction projects, Continuously improve the bidding management to ensure orderly competition in the market, Can ensure the vitality of the market economy. To make the bidding market fair and standardized, the improvement measures are not single, but must be a set of " combination boxing". In view of the problems existing in the current bidding process in our country, we will improve it so that the whole bidding process can be supervised, controlled and managed, and the real fairness, fairness and efficiency of public resources trading in construction projects can be realized. Laying a good foundation for the sustained and healthy development of our country's construction projects.

\section{Acknowledgements}

This work was financially supported by Project Program of Chongqing Municipal Education Science (2017-GX-338),Major cultivation program of Chongqing University Of Arts And Sciences (P2017JG19),Jeneral program of Chongqing University Of Arts And Sciences (Y2016JG44) and Jeneral program of Chongqing University Of Arts And Sciences (Y2015JJ41)

\section{References}

[1] Shaotang Liu,Di Zhang, Guo Wang, Baoxiang Gu . Research on problems and countermeasures in project bidding [J]. Tendering and bidding research,2017, (11) : 40-44.

[2] Chuang Zhu. Problems and countermeasures in bidding for construction projects [J]. Research on financial issues,2014, (5): 186-189.

[3] Jinhong Wei .Problems and countermeasures in the bidding process of construction projects [J]. Journal of Shanxi university of finance and economics,2014,36 (S1) : 81.

[4] Lingling Zhong . Common problems and countermeasures in project bidding management [J]. Building materials and decoration,2017. 